\title{
Studies on some prevailing parasites affecting Oreochromis niloticus fingerlings with a trial of treatment
}

\author{
Abbas A. Younis ${ }^{1}$, Abd El-Tawab F. Gharib ${ }^{2}$ and Ebtsam A. A. Tantawy ${ }^{1}$ \\ 1- Fish Diseases Department, Animal Health Research Institute, Dokki Giza \\ 2- Giza Provincial Lab., Animal Health Research Institute
}

\begin{abstract}
Three hundred and fifty naturally infested Oreochromis niloticus fingerlings were collected from a cultured fish farm. They were examined for external Protozoa, monogenetic and digenetic parasites. The prevalence of isolated Protozoa showed high infestation rates with Trichodina mutabilis $(71.3 \%)$, Chilodonella hexasticha (60\%). Monogenetic flukes (Gyrodactylus rysavyi) had infestation rate of $40 \%$, while digenetic larvae (Hetrophyid metacercariae) showed an infestation rate of $66.6 \%$. The morphometric characters of isolated parasites were determined. Anorexia was the main clinical sign recorded with slimness of the skin, presence of scattered haemorrhagic spots, detached scales and restlessness. Mortality rate was $15 \%$ among examined fish.

Comparative treatment of the infested fish with formalin $(20 \mathrm{ppm})$ and potassium permanganate $2 \mathrm{ppm}$ for $48 \mathrm{hr}$ bath was recorded. Besides, the adverse effects of such drugs on water quality were studied. Such drugs showed effectiveness against Trichodina, Chilodonella and Gyrodactylus, although marked decrease in dissolved oxygen and increase in nitrite was recorded. The value $\mathrm{pH}$ decreased in case of formalin and increased in case of potassium permanganate.
\end{abstract}

\section{INTRODUCTION}

Oreochromis niloticus represents the main popular cultured fish produced in Egypt. Parasitic infestations, especially ectoparasites from Protozoa, monogenetic and digentic flukes are the most dangerous groups affecting skin and gills that induces slimness of the skin, irritation, destruction of gills, anorexia and impaired breathing (Lom, 1995). The synergistic action of the parasites may cause mortalities (Osman, 2001).

Ectoparasitic ciliates include species that are the most common parasites of fishes (Lom, and Dyková, 1992). Trichodina spp. as well as Chilodonella spp. causes $70 \%$ mortality among 2-month old fry of cultured grass carp (Uzbilek and Yilidiz, 2002). Trichodina glides rapidly over the gills and skin, affects all fish species causing direct or indirect death (Durborow, 2003). Trichodinids commonly occur in association with other ectoparasites, especially, monogenic and digenic flukes (Pearse, 1972).

Monogenean flukes are a group of parasites best described as flatworms commonly found on the gills, skin or fins of fishes have a series of hooks that attach to the fish causing irritation, excessive mucus production (Reed et al. 
2003). Fish may undergo flashing and have fraying of fins. Severe infection (gills) may cause the fish to become dyspneic and die (Moeller, 2001). Numerous Gyrodactylidae spp. affect the skin, fins and also gills of a wide variety of marine and freshwater teleosts (Soulsby, 1982).

Digenetic trematodes are helminthes that require several hosts on which to complete their life cycle. The majority of digenetic trematodes that infect fish do so as a metacercaria or "grub" stage (Bowser, 1999). Metacercarial infestation in fish has economic losses (Paperna, 1991). The incidence of Heterophyid encysted metacercariae in gills of Oreochromis niloticus fingerlings in Abbassa aquaculture was $98.46 \%$ (Ramadan et al., 2002) while it was $46 \%$ in Common Carp gill (Abd EL Hady, 2007).

Formalin bath is effective for controlling Protozoa and monogenean infestations in freshwater fish (Reed et al., 2003). Potassium permanganate (KMnO4) is one of the widely used inorganic chemicals worldwide; it has been used as a water/bath treatment for protozoan and monogenetic flukes in commercial and ornamental fish at $2 \mathrm{ppm}$ (Marecaux, 2006). Formalin causes decline of dissolved oxygen from 10.1 to 3.0 with $36 \mathrm{hr}$ of treatment in addition to $\mathrm{pH}$ decline from 7.2 to 6.3 (Rowland et al, 2006), while potassium permanganate tended to increase $\mathrm{pH}$ and total alkalinity (Kori-Siakpere, 2008).

Therefore, the present work was carried out to detect the prevalence and intensity of different parasites in naturally infested $O$. niloticus fingerlings with a trial for treatment of such parasites either by using formalin or potassium permanganate with reference to water quality.

\section{MATERIAL AND METHODS}

1-Fish: A total number of 350 naturally infested freshwater cultured $O$. niloticus fingerlings with a total length of 7-10 cm and body weight of $12-15 \mathrm{~g}$ were collected from a cultured fish farm at Giza. Fish were transported alive in large plastic bags to the Fish Diseases Department, Animal Health Research Institute, Dokki, Giza. They were acclimatized to Lab conditions in glass aquaria with aerated chlorine free tap water, while temperature was thermostatically adjusted at $23.2 \pm 1{ }^{\circ} \mathrm{C}$. Fish were fed commercial ration twice a day.

\section{2-Chemicals:}

A- Potassium permanganate was available in the form of crystals from El-Nasr Co - Egypt. It was used at a dose of $3 \mathrm{mg}$ for $24 \mathrm{~h}$ according to Marecaux, (2006).

B- Formalin obtained from Sturat Adwia Co., Egypt and used by a dose of 20 ppm for $24 \mathrm{~h}$ according to Lom (1995).

\section{3-Experimental design:}

\section{A- Clinical picture:}

Two hundred naturally infested fish were continuously examined for gross clinical picture according to Noga (1996). 


\section{B- Parasitological examination:}

Naturally infested fish were examined according to the method described by Paperna (1996) for the presence of external Protozoa, monogenetic and digenetic parasites, where the prevalence, intensity and identification of each parasite were recorded.

C-Treatment trial: 150 naturally infested $O$. niloticus fingerlings were divided into 3 equal groups; 50 each. First group was treated with $20 \mathrm{ppm}$ formalin, while, the $2^{\text {nd }}$ group was treated with $2 \mathrm{ppm}$ potassium permanganate as permanent bath according to Lom (1995) and Marecaux (2006). The $3^{\text {rd }}$ infested group was kept as a control group for parasitic investigation and for studying the adverse effects of the used drugs. Temperature was adjusted at $23.2 \pm 1{ }^{\circ} \mathrm{C}$ at the beginning of experiment. The severity of infestation with the parasites was assened by counting the parasites per microscopic field pre and post treatment, according to El-Khatib (1993). For studying the effects of the tested drugs on ectoparasitic infestation, skin and gill smears were taken just before treatment and after the exposure to the used drug. Also water sample was taken just before and after $48 \mathrm{hr}$ of exposure to the used drug for studying the effects of the tested drugs on the water quality, while water temperature was measured daily.

\section{D-Water quality:}

1-Temperature: The temperature $\left({ }^{\circ} \mathrm{C}\right)$ was measured by dipping a dry bulb thermometer to about $10 \mathrm{~cm}$ below the water surface in each stabilize and allowed to equilibrate for $5 \mathrm{~min}$ before the reading was taken.

2-Hydrogen ion concentration (pH): Ten (10) $\mathrm{ml}$ of water sample was drawn from the aquaria and transferred into a beaker; and the $\mathrm{pH}$ reading was taken with a $\mathrm{pH}$ meter.

3-Dissolved oxygen: was determined by using oxygen meter

4-Nitrite $\left(\mathbf{N O}_{2}\right)$ : Determination of nitrite by kits of Hanna instruments, Standered methods for the examination of water and Wastewater, $18^{\text {th }}$ edition (1992).

\section{Clinical examination:}

\section{RESULTS AND DISCUSSION}

The present study revealed that naturally infested $O$. niloticus fingerlings with parasites revealed in a sequence of progressive signs as slimy pale skin, detached scales and presence of haemorrhagic lesions on the skin, fins and gills, anorexia and signs of asphyxia, manifested by rapid breathing and aggregation of fish near the water surface. The skin where the flukes were attached, showed areas of scale loss and may ooze a pinkish serous fluid in some fish. Heavy gill infestations revealed increased respiratory rate and fish were less tolerant to low oxygen conditions. Gulping air at the water surface and "Piping" may be observed in fish with severe respiratory distress. Large numbers of parasites on either the skin or gills may result in mortality. Mortality rate among examined fish was $15 \%$. Most of these clinical signs coincided with those observed by Post (1987), Schaperclaus (1992), Noga (1996), Dey and Chandra (1998) and Yousef 
(2008). Damaged gills, filaments caused by trematodes infestations were reported as the main cause of asphyxia and respiratory dysfunction (Cone, 1995; Reed et al., 2003). Scales sloughing as well as skin, fins and gills haemorrhages, could be attributed to continuous irritation of Trichodina adhesive discs and the feeding activities of monogenetic flukes and the action of their hooks (Schaperclaus, 1992; Reed et al., 2003) In our study, respiratory dysfunction may also be due to penetration and encystation of metacercarial in gill tissues. This agrees with Lemy and Esch (1984) and Farstey (1986).

Parasitological examination: Based on the morphological and parasitological examination of the isolated parasites from skin, fins and gills of the infested $O$. niloticus fingerlings, the recovered parasits belonged to the genera of Trichodina, Chilodonella (ciliated Protozoa), Gyrodactylus (Monogenea) and hetrophyid metacercariae (Digenea) by ratios of 71.3, 60, 40 and $66.6 \%$ respectively, while the degree of infestation was moderate as shown in table (1). The high prevalence of Trichodina may be due to the low specificity to its host species which agrees with Lom (1995). The obtained results disagree with that of Vargas et al. (2000) who reported Trichodina spp. and monogenea in fingerlings of Nile tilapia by raties of $36 \%$ and $15 \%$ respectively.

Table (1): Prevalence and intensity of infestation with external parasites recovered from Oreochromis niloticus fingerlings.

\begin{tabular}{|c|c|c|c|c|}
\hline \multirow{2}{*}{ Parasites } & \multirow{2}{*}{$\begin{array}{l}\text { No. } \\
\text { examined } \\
\text { fish }\end{array}$} & \multicolumn{2}{|c|}{ Total infestation } & \multirow{2}{*}{$\begin{array}{l}\text { Intensity of } \\
\text { infestation* } \\
\text { (No./M.F) }\end{array}$} \\
\hline & & No. & $\%$ & \\
\hline \multirow{4}{*}{$\begin{array}{l}\text { 1- Trichodina } \\
\text { 2- Chilodonella } \\
\text { 3- Gyrodactylus. } \\
\text { 4- Hetrophyid metacercariae }\end{array}$} & \multirow{4}{*}{150} & 107 & 71.3 & $15-20$ \\
\hline & & 90 & 60 & $10-13$ \\
\hline & & 60 & 40 & $3-10$ \\
\hline & & 100 & 66.6 & $3-5$ \\
\hline
\end{tabular}

* Number of parasites per microscopic field

The morphological characteristics of Trichodina mutabilis (Kazubski et Migala, 1968) (Fig.1).

Kingdom: Protozoa, Phylum: Ciliophora; Class: Ciliatea; Order: Mobilina Family: Trichodinidae, Genus: Trichodina, Trichodina mutabilis (Kazubski et Migala,1968) is medium to large disc shape provided with several rows of cilia at the circular periphery and a circle of more centrally laying hooklets. Denticle blade oblong, largely barrel to radial disc, with squared distal end, central part narrow with oblong to round overlapping end.

The morphological characteristics of Chilodonella hexasticha (Kiernik, 1909) (Fig. 2).

Kingdom: Protozoa, Phylum: Ciliophora, Class: Ciliata, Order: Cyrtophorida Family: Chilododontidae, Genus: Chilodonella, Chilodonella hexasticha (Kiernik, 1909) is a ciliated large protozoan, heart-shaped ciliate (60 to $80 \mathrm{~m}$ ) with bands of cilia along the long axis of the organism. The ventral side was flat 
with barrel ciliary rows, the dorsal surface was slightly convex and lacked cilia except in the oral groove at the extreme anterior end (35-39 um) in length and (23-25 um) in width. The macronucleus was rounded.The morphological characteristics of Trichodina mutabilis as well as Chilodonella hexasticha were nearly similar to that described by Lom and Dyková (1992), Lom (1995), Noga (1996) and Paperna (1996). The morphological characteristics of Gyrodactylus rysavyi (Ergens, 1973) (Fig. 3). Phylum: Platyhelminthes, Class: Trematoda Subclass: Monogenea Order Gyrodactylidea, Family Gyrodactylidae Genus: Gyrodactylus. Gyrodactylus rysavyi (Ergens, 1973). It is described as flatworms, with two lobed projections on the anterior end and the chief attachment organ (opisthaptor) is posterior, more or less discoid, muscular, provided with paired anchors and a twenty smaller hooks. Each individual parasite has both male and female reproductive organs. The morphological characteristics agree with that reported by Moravec et al. (1991), Cone (1995) Noga (1996) and Reed et al. (2003).

The detected hetrophyid metacercariae from gills (Figs. 4 \& 5) are spherical encircled by two thin layers and measure $0.13-0.20 \mathrm{~mm}$ in diameter The oral and ventral sucker are well developed. The oral sucker terminated with circumoral spines as reported by Tantawy (1997) and Abu El- Ezz et al. (2000).

The effect of potassium permanganate and formalin on the degree of parasitic infestation and mortality rate of $O$. niloticus fingerlings were shown in Table (2).

Table (2): Effect of formalin and potassium permanganate on the intensity of parasitic infestation in Oreochromis niloticus fingerlings.

\begin{tabular}{|c|c|c|c|c|}
\hline $\begin{array}{ll}\text { Eroup } & \text { Ectoparasites }\end{array}$ & Trichodina & Chilodonella & Gyrodactylus & $\begin{array}{r}\text { Heterophyid } \\
\text { metacercariae }\end{array}$ \\
\hline $\begin{array}{l}1^{\text {st }} \text { infested fish group pre } \\
\text { treatment } \\
1^{\text {st }} \text { infested group post } \\
\text { treatment with potassium } \\
\text { permanganate }\end{array}$ & ++ & + & + & $\begin{array}{l}++ \\
++\end{array}$ \\
\hline $\begin{array}{l}2^{\text {nd }} \text { infested fish group } \\
\text { pretreatment } \\
2^{\text {nd }} \text { infested group post } \\
\text { treatment with formalin }\end{array}$ & ++ & + & + & $\begin{array}{l}++ \\
++\end{array}$ \\
\hline $\begin{array}{l}3^{\text {rd }} \text { infested group } \\
\text { pretreatment } \\
3^{\text {rd }} \text { infested group without } \\
\text { treatment }\end{array}$ & $\begin{array}{c}++ \\
+++\end{array}$ & ++ & $\begin{array}{l}+ \\
++\end{array}$ & $\begin{array}{l}++ \\
++\end{array}$ \\
\hline
\end{tabular}

+ Light infestation protozoa 1- 10, monogenia 2- 5,

++ Moderate infestation: protozoa 12- 17, monogenia 10- 20. digenia 3-5

+++ Heavy infestation protozoa 20-30, monogenia 21-35.

The two used drugs were highly effective against ectoparasitic infestations (Trichodina, Chilodonella and Gyrodactylus). These results nearly agree with findings given by Stuart (1983); Younis (1993, 1999), Brown (2000), 
Tantawy and Younis (2003) and Rowland et al. (2006). The obtained results agree also with Reed et al. (2003) who mentioned that formalin bath is effective for controlling protozoan and monogenean infestations in freshwater fish. From the present results, the two drugs did ret affect heterophyid metacercariae, which remain viable, surrounded by thick fibrous capsule and need special treatment as recorded by Tantawy (2004). Also, from Table (2) it is clear that, parasitic infestations were increased in parasitic non treated group with $20 \%$ mortality rate. This agrees with Uzbilek and Yilidiz (2002) who recorded 70\% mortality among 2-months old fry of cultured grass carp infested with Trichodina and Chilodonella and Kim et al. (2002) who recorded that monogeneaus caused losses among 15 species of ornamental fish in korea.

Comparative study on the effect of formalin and potassium permanganate on water quality was recorded in Table (3) Both of them cause decrease of dissolved oxygen .This result agrees with Hazen and Sawyer (1992 who reported that $5 \mathrm{mg} / \mathrm{L}$ of formalin remove $1 \mathrm{~g}$ of dissolved oxygen. This is one reason why using of formalin in ponds is discouraged. It also agrees with Kori-Siakpere (2008) who recorded that potassium permanganate decrease oxygen level. Potassium permanganate loses two oxygen atoms and is reduced to insoluble manganese dioxide $\mathrm{MnO}_{2}$. The lost oxygen atoms react aggressively with parasites altering their structure and properties which lead to their mortality. Insoluble manganese dioxide may precipitate on the gills causing respiratory problems. This agrees with results of Hazen and Sawyer (1992), Rowland et al. (2006) and Kori-Siakpere (2008).

Table (3): Effect of formalin and potassium permanganate as water bath for $48 \mathrm{hr}$ on water quality at $23.2 \pm 1{ }^{\circ} \mathrm{C}$

\begin{tabular}{|l|c|c|c|}
\hline parameter & $\begin{array}{c}\text { Formalin } \\
20 \mathrm{ppm}\end{array}$ & Potassium permanganate 2ppm & $\begin{array}{c}\text { Control } \\
\text { (Non treated) }\end{array}$ \\
\hline Dissolved oxygen (DO) & $6.0^{\circ} \mathrm{C}$ & 6.4 & 7.5 \\
\hline Nitrite $\left(\mathrm{NO}_{2}\right)$ & $0.45 \mathrm{mg} / \mathrm{L}$ & $0.40 \mathrm{mg} / \mathrm{L}$ & $0.35 \mathrm{mg} / \mathrm{L}$ \\
\hline $\mathrm{pH}$ & 5.5 & 8.8 & 7.2 \\
\hline
\end{tabular}

So during treatment with potassium permanganate and formalin, the oxygen supply to the treated fish should be increased to avoid the bad effect of oxygen decrease.

It is also clear from Table (3) that nitrite and $\mathrm{pH}$ were increased than in the control except in case of formalin, where $\mathrm{pH}$ was decreased. This agrees with Rowland et al. (2006) and Kori-Siakpere (2008). These changes represent a stress factor to fish as reported by Noga (1996) that at low $\mathrm{pH}$, the toxic metal becomes rapidly dissolved in water and can flux through the permeability of gills causing toxicity, while in alkaline water ammonia changes into unionized form that can enter the body of fish through the permeability of gills and cause 
mortality. These results agree also with that of Hazen and Sawyer (1992) who recorded that nitrite and $\mathrm{pH}$ should be closely monitored following treatment with potassium permanganate. Also, Noble and Summerfelt (1996) reported that high nitrite acts as a physical streamer affecting on defense mechanism and immune response of fish especially younger fish.

From the present study, it was concluded that ectoparasitic infestation in $O$. niloticus should be diagnosed and treated quickly to avoid their rapid spread among fish farms, minimizing the morbidity and mortality rates and to avoid secondary bacterial or fungal infections. Also, treatment either by potassium permanganate or formalin seems to be of a great success for the control of parasitic infestation under enough oxygen supply to avoid the bad effect of decreased oxygen.

\section{REFERENCES}

Abd EL-Hady Y. M. (2007). Prevalence of parasitic infestation affecting the gills of fingerlings of the Common carp, Cyprinus carpio with trials for control. The $11^{\text {th }}$ conference of the Egyptian Socity for the Development of Fisheries Resources \& Human Health. The International Arab African Fish Resources Conference \& Exhibition.

Abu El- Ezz N.M .T.; Tantawy E. A. ; Mahdy O. A. and El-Massry A. A. (2000). Studies on Heterophyid infections among some fishes in Egypt. Egypt, J. Vet. Sci., 34: 11-29.

Bowser, P. R. (1999). Diseases of Fish. Ithaca, New York 14853-640

Brown, K. M. (2000). Applied fish pharmacology kluwer Academic publishers. Dooedrecht, Boston, London.

Cone, D.K. (1995). Monogenea (Phylum Platyhelminthes) cited by Woo, P.T.K. (1995) Fish Diseases Disorders.1; Protozoa, metazoan, infections CAP International.

Dey, R. K. and Chandra, S. (1998). Observations on Trichodinosis in the Indian major carp seed (fry) and its control through herbal material. Technological advancements in Fisheries proceedings of the National symposium on Rural development held at Cochin by 
school of Industrial Fisheries, Cochin University of science and Technology during December 5-7 1995. Hameed, M.S.(ed). Kurup, B.M. (ed). Cochinn India Cusat, pp. 158-160.

Durborow, R. M. (2003). Protozoan parasites. SRAC publication No. 4701(http:// srac. Tamu.edu/4701fs.pdf.) October 2003.

El- Khatib Nahla, R. H. (1993). Further studies on ectoparasitic infestation in fresh water fish. Ph. D. Vet Thesis, Cairo Univ.

Farstey, V. (1986). Centrocestus sp. (Hetrophyidea) and other trematode infections of the snail Melanoides tuberculata and Cichlid fish at lake Kinneret. Unpublished Msc. Thesis, Hebrew Univ. of Jerusalem, 1986 (Hebrew text, English summery).

Hazen and Sawyer. (1992). Disinfection Alternatives for Safe Drinking Water. Van Nostrand Reinhold, New York, NY.

Kim, J. H.; Hayward, C. J. I.; Joh, S. J. and Heo, G. J. (2002). Parasitic infection in live freshwater tropic fishes imported to Korea. Dis. Aquat. Organ. Nov. 22, 52 (2): 169-173.

Kori-Siakpere, O. (2008). Acute toxicity of potassium permanganate to fingerlings of the African catfish, Clarias gariepinus (Burchell, 1822). African Journal of Biotechnology, 7 (14): 2514-2520.

Lemy, A. D. and Esch, G. W. (1984). Effect of the trematodes Uvulifer ambloplites on Juvenile bluegill sunfish J. Parasitol., 70: 472-492.

Lom, G. (1995). Trichodinidae and other ciliates (Phylum Ciliphora). Cited by Woo, P.T.K. (1995) Fish Diseases Disorders Protozoa, metazoan, infections CAP International.

Lom, J. and Dykova, I. (1992). Protozoan parasites of fishes. Elesevier Science Puplishers, Amsterdam. 242 pp. 
Marecaux, E. N. (2006). Effects of potassium permanganate on the sailfin molly, Poecilia latippinna, at varying salinity levels. M. Sc Thesis, Graduate School, University of Florida, 45 pp.

Moravec, F.; Ergens, R.; Našincová, V. and Scholz T. (1991). Parasitic metazoan. In Manual for International Training Course on FreshWater Fish Diseases and Intoxications: Diagnostics, Prophylaxis and Therapy Edited by: Z. Svobodová, B. Vykusová Research Institute of Fish Culture and Hydrobiology Vodňany, Czechoslovakia.

Moeller, R. B (2001). Diseases of fish. California Animal Health and Food Safety Laboratory System. Univ. of California 18830 Road 112 Tulare, California 93274- 559- 688- 7543 rbmoeller@ucdavis.edu.

Noble, A. C. and Summerfelt, S. T. (1996). Diseases encountered in rainbow trout cultured in reciculating systems...Annual Review of Fish Diseases, 6: 65-92.

Noga, E. J. (1996). Fish diseases diagnosis and treatment Mosby Electronic Publishing USA, 163pp.

Osman, A. F. M. (2001). Studies on parasitic gill affections in some cultured fresh water fishes. Vet Thesis, M.V. Sc. Suez Canal Univ.

Paperna, I. (1991). Diseases caused by Parasites in aqua culture of warm water fish Annual Rev. Fish Dis. 155pp.

Paperna, I. (1996). Parasites, infections and diseases of fishes in Africa FAO, CIFA Techincal Paper, 563pp.

Pearse, L. C. (1972). A note on a marine trichodinid ciliate parasitic on the skin of captive flatfish. Aquacult., 1: 261-266. 
Post, G. (1987). Textbook of Fish Health T.F.H. publications, Inc. Neptune City New Jersey, USA. Pp.159- 214

Ramadan, R. A. M; Saleh, F. M. Sakr and Refaat, M. El- Gamal (2002). Prevalence and Distribution of Metacercariae of Centrocestus sp. (Trematode Heterophyidae) on gills and other organs of Oreochromis niloticus fingerlings Suez Canal Vet. Med. J. 92: 657-667.

Reed, P.; Ruth F. F. and Ruth, E. K.(2003). Monogenean Parasites of Fish. This document is FA-28, one of a series from the Department of Fisheries and Aquatic Sciences, Florida Cooperative Extension Service, Institute of Food and Agricultural Sciences, University of Florida. Reviewed September 2003. Visit the EDIS Web Site at http://edis.ifas.ufl.edu

Rowland S. J; Mark, N.; Matthew, L.; Charlie M.; Phil R. and Peter, B. (2006). Effects of formalin on water quality and parasitic monogeneans on silver perch (Bidyanus bidyanus Mitchell) in earthen ponds. Aquacult., Res., 37(9): 869 - 876.

Schaperclaus, W. (1992). Fish Diseases. Vol.2 A. A. Blakema, Rotterdam, Berlin.

Soulsby, E. J. L. (1982). Helminths, arthropods and protozoa of domesticated animals. $7^{\text {th }}$ Ed., ELBS, London

Stuart, N.C. (1983). Treatment of fish diseases Vet. Rec.,19: 173- 177.

Tantawy Ebtsam, A. A. (1997). Safety and quality of fishes infested with parasites M.V.Sc., Cario University.

Tantawy Ebtsam, A. A. (2004). Trial to control the Heterophyid and Echinostomatid metacercariae infesting Oreochromis niloticus in Aquaculture by Praziquantel "Droncid". National Research Center, First International Conference of The Veterinary Research Division. (15-17 Feb. 2004). 
Tantawy Ebtsam, A. A. and Younis, A. A.( 2003): Comparative study on the effect of formlin and garlic on ectoparasites infestation $O$. niloticus fish with reference to their effect on blood picture and serum constituents Egypt. J. Agri. Res., 81 (1)

Uzbilek, M. K. and Yilidiz, H. Y. (2002). A report on spontaneous diseases in the culture of grass carp Turkey.Turk Veterinerlik Ve Hayvancilik Dergisi 26: (2) 407- 410.

Vargas, L; Povh, J. A.; Ribero, R. P. and Moreira, H. L. M (2000). Occurrence of ectoparasihic in tilapia (Oreochromis niloticus) of Thailand origin, in Maringa-parana. Arquivos de cun cias Veterinarias e Zoologia da UNIRR, 3 (1): 31-37.

Younis, A. A. (1993). Pharmacological studies on copper sulphate and methylene blue in Clarias lazera fish. Ph. D. Vet. Thesis, Cairo Univ.

Younis, A. A. (1999). Effect of some ectoparasites on the blood and serum constituents of Oreochromis niloticus fish with referring treatment Beni- Suef Vet. Med. J., 9 (3- A): 341- 351.

Yousef Nesreen, S. A. I. (2008). An Approach to ectoparasitic infestation in some cultured fishes in Egypt. M.V. Sc. Vet. Thesis, Cairo Univ. 
Fig. (1): Trichodina mutabilis, Silver imprgnation X40

Fig. (2): Chilodonella hexasticha.

Silver imprgnation X40

Fig. (3): Gyrodactylus rysavyi

1-Prohaptor (2 lobes).

2-Uterus.

3-Embryos.

4-Central hooks.

5-Marginal hooklets.

Fig. (4):Hetrophyhid metacercaria in gill filament (X 100)

1-Oral sucker with circumoral spines.

2-Ventral sucker.

3-Thick fibrious cyst wall.

Fig. (5): Hetrophyhid metacercariae in gill filaments (X 40) 

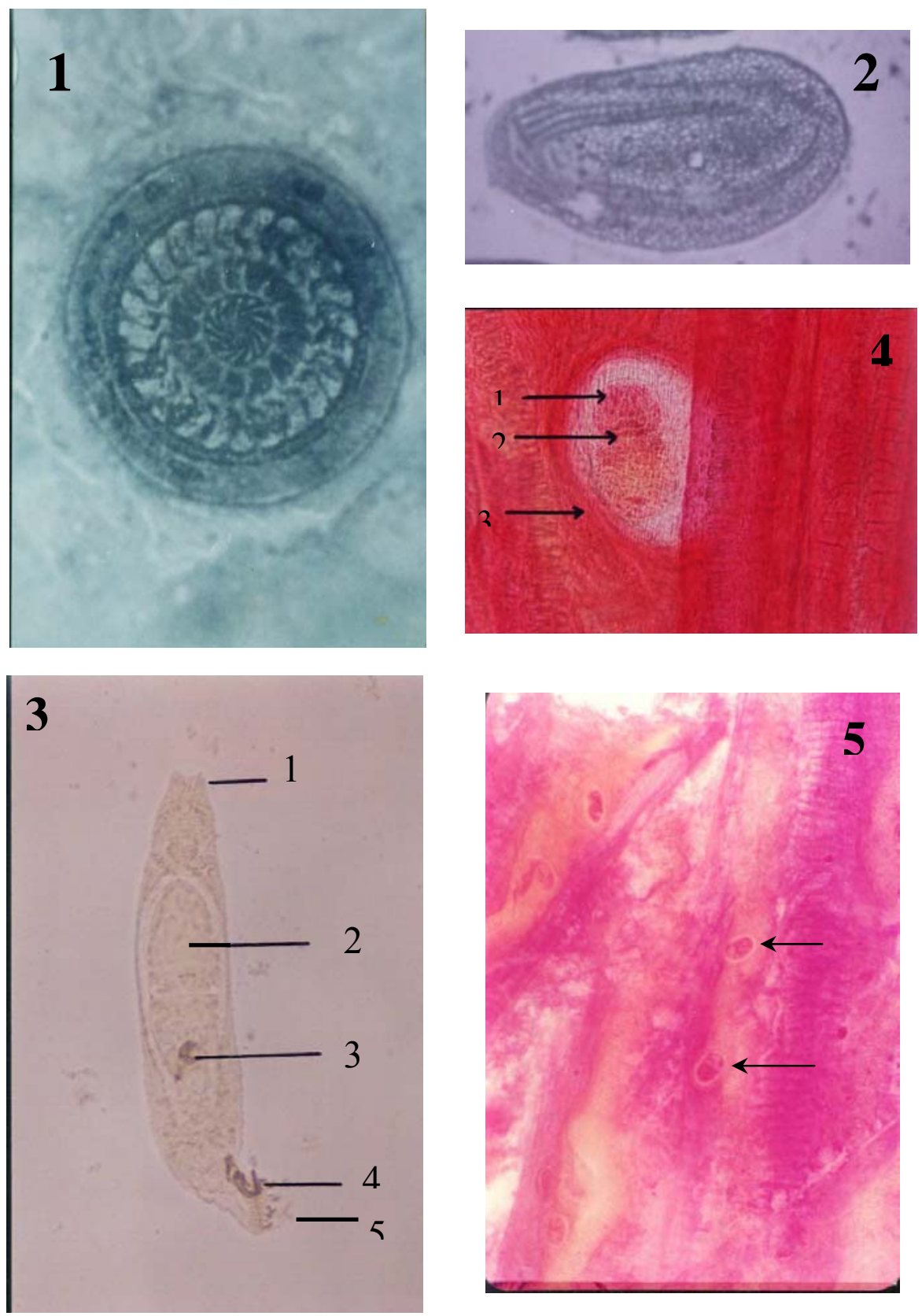